\title{
Process Plant Design and Feasibility of an Acetone-Butanol-Ethanol (ABE) Fermentation Biorefinery using Sugarcane Bagasse and Clostridium acetobutylicum
}

\author{
Charlimagne M. Montealegre, John Mark Edrhum M. Ani, Onella Kezia B. Castro, and Lara Louise R.
} Llanera

\begin{abstract}
The acetone-butanol-ethanol (ABE) fermentation process is a promising technology which utilizes renewable resources such as sugarcane bagasse into a number of products with high market value. In the proposed plant design, sugarcane bagasse will be used as the raw material in the $\mathrm{ABE}$ fermentation with Clostridium acetobutylicum. For the analysis, it is assumed that sugarcane bagasse will be purchased and transported from established sugar mills. Using dilute acid hydrolysis, celluloses and hemicelluloses present in bagasse will be converted to glucose. The extracted glucose will proceed to the fermentation step in order to be converted to $\mathrm{ABE}$ products. Corresponding purification steps follow, based on the required purity grades of the products. The feasibility study aims to produce 157,853 tons of products per annum, catering a variety of industries such as the chemical, paint, polymers, plastic, food, and pulp and paper industries, among many others. The proposed design achieved a market value of USD 528 million from 350,460 tons of bagasse per annum and $28 \%$ internal rate of return.
\end{abstract}

Index Terms-ABE fermentation, bagasse, biorefinery, process design.

\section{INTRODUCTION}

There is an ever-increasing demand for energy, and currently, the world is highly dependent on exploiting non-renewable resources. The limited supply of fossil fuels and volatile prices of crude oil call for more sustainable energy sources, one of which is biomass. Generation of fuels from biomass-based plants has garnered much attention, including ethanol produced from corn and sugarcane. However, competition between food supply and raw material supply for fuel could pose several problems. Sugarcane bagasse, one of the wastes in the sugar industry, contains enough sugars to provide for a fully functioning biomass-based plant.

Acetone-Butanol-Ethanol process or ABE process utilizes biomass as a raw material for the production of alcohols and solvents. The fermentation of glucose is carried out in an anaerobic bioreactor using bacteria. Among a number of microbial strains producing butanol, C. acetobutylicum is the most extensively used species for industrial fermentation. Other strains include C. beijerinkii, C. aurantibutyricum, and C. tetanomorphum. Studies on the aforementioned

Manuscript received January 20, 2017; revised May 19, 2017.

The authors are with the Department of Chemical Engineering, College of Engineering, University of the Philippines Diliman, Quezon City 1101 Philippines(e-mail: cmmontealegre@up.edu.ph, ani.edrhum@yahoo.com, larallanera@gmail.com, keziaaa.castro@yahoo.com). microorganisms show higher yields of the products because of their higher resistances to substrate and product inhibitions as compared to C. acetobutylicum. Unfortunately, there were only limited taxonomic studies undertaken, all of which are of laboratory-scale, and there are no available approved standards for the classification of these microorganisms yet. Hence, the selection of strains for industrial-scale fermentation is based on the nature of raw material utilized, the ratio of end-products required, the need for supplementary nutrients, and data availability on product yield for an industrial-scale process [1]. Since 1912, C acetobutylicum has already been studied and data are well-documented for fermentation. Kinetic models and mechanisms have been established for the production of butanol.

\section{METHODS}

\section{A. Process Description}

The proposed design for the batch $\mathrm{ABE}$ fermentation process can be divided into three main parts: purification of feed, fermentation process and recovery of products. Acetone, butanol, ethanol, carbon dioxide and hydrogen are produced by the fermentation process of $C$. acetobutylicum using glucose as the primary substrate.

\section{B. Economic Analyses}

Equipment sizing was performed by manual calculations, engineering heuristics [2] for process equipment and simulation in Hysys ${ }^{\mathrm{TM}}$. Equipment costs are calculated based on heuristics given [3]. For uncommon equipment, costs were estimated from papers with market considerations such as that of pressure swing adsorption for hydrogen purification [4] normalized in the year 2016 by accounting the chemical engineering plant cost index (CEPCI 2004: 444.2 and CEPCI 2016: 624.52 by extrapolation) [5]. Furthermore, fermenter costs are estimated using capacity-dependent costing in SuperPro ${ }^{\mathrm{TM}}$.

The total capital investment (TCI) was calculated based on established methods [2]. The percentage values of TCI were adopted from an ABE batch plant in 2000 while the rest of the direct and indirect field costs are estimated to be of the following percentages shown in Table I, calculated based from previous economic analysis of $\mathrm{ABE}$ fermentation in 1980 [6].

Finally, the sensitivity of the profitability of the process plant with respect to fixed capital investment (FCI), sales and cost of goods sold (COGS) are investigated. 
TABLE I: BREAKDOWN OF INSIDE BATTERY LIMITS INVESTMENT $\%$ of FCI

\begin{tabular}{lc}
\hline Direct Cost & 7 \\
Piping & 5 \\
Instruments & 4 \\
Electrical & 4 \\
Civil & 3 \\
Buildings & 2 \\
Lagging & 16 \\
Services, yard & \\
Indirect Cost & 15 \\
Engineering and supervision & 15 \\
Construction expenses & \\
\hline \hline
\end{tabular}

\section{RESULTS}

\section{A. Process Synthesis}

Process flow diagrams (PFD) for the proposed process were developed and are shown in Fig. 1 to 8 . The pretreatment process was divided into sections 100, 200 and 300. The fermentation process was divided into sections 400 and 500. The purification process was divided into sections 600,700 and 800.

\section{B. Pretreatment}

Pretreatment begins with the hemicellulose hydrolysis section in Fig. 1. Sugarcane bagasse enters the ball mill at a rate of $44,250 \mathrm{~kg} / \mathrm{h}$ to be homogenized at a size of 0.212 to $1.18 \mathrm{~mm}$. The bagasse is then washed and sent to a heating vessel together with $200,340 \mathrm{~kg} / \mathrm{h}$ of $2 \mathrm{wt} \%$ sulfuric acid solution. The mixture is then pumped to $300 \mathrm{kPa}$ and sent to the reactor vessel which acts like a flash. The hemicellulose is converted to sugars, while the cellulose and lignin remain as solids. The liquid mixture is sent to a filter, where the lignocellulose is sent to the next section and the pentose liquor is sent to a third-party wastewater treatment.

The delignification section in Fig. 2 utilizes the Organosolv technology. Organosolv is a solvent of $60 \mathrm{wt} \%$ ethanol and $40 \mathrm{wt} \%$ water. The solvent dissolves the lignin but keeps the cellulose as solids. Lignocellulose is pumped to $1900 \mathrm{kPa}$ before it is sent to a reactor with organosolv heated to $180^{\circ} \mathrm{C}$. The mixture proceeds to a flash drum at $850 \mathrm{kPa}$. Steam is vented out and the liquid mixture is filtered. The solids and a few amount of water proceed to cellulose hydrolysis, and the spent organosolv with the dissolved lignin is sent to the solvent recovery system.

From the delignification section, the cellulose mixture at $35,553 \mathrm{~kg} / \mathrm{h}$ enters a mixer with $209,497 \mathrm{~kg} / \mathrm{h}$ of water and $8,888 \mathrm{~kg} / \mathrm{h}$ of $2 \mathrm{wt} \%$ sulfuric acid shown in in Fig. 3. The mixture is pumped to $3600 \mathrm{kPa}$, heated to $205^{\circ} \mathrm{C}$ and flashed The steam is vented out and the hexose liquor is cooled from $205^{\circ} \mathrm{C}$ to $90^{\circ} \mathrm{C}$ by the organosolv and dissolved lignin stream from the previous section. The hexose liquor is first filtered to remove any unreacted solids and remaining ashes. The solids are sent to a third-party waste treatment. The liquid proceeds to a three-effect evaporator. The glucose-rich liquor then proceeds to a storage tank before it is used in the fermentation section.

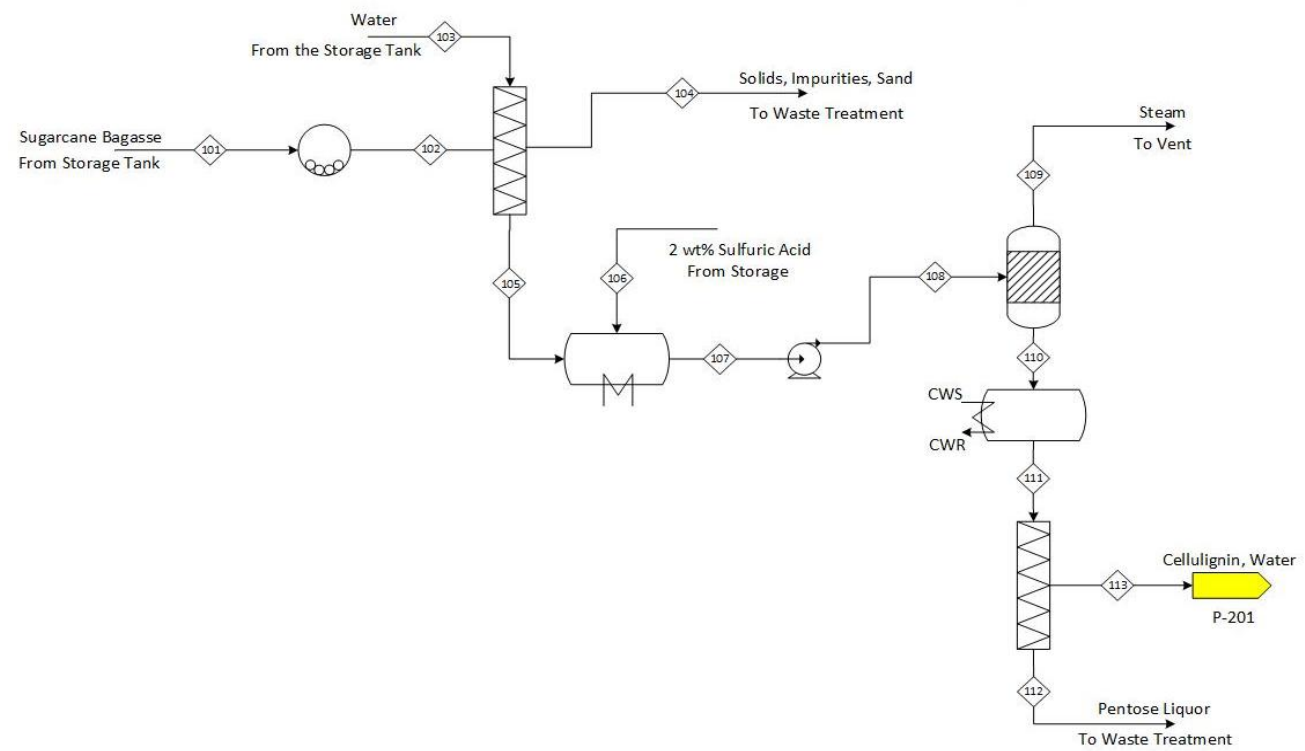

Fig. 1. The first pretreatment process is Unit 100, Cleaning and Hemi-cellulose Hydrolysis, where sugarcane bagasse is converted to cellulignin .

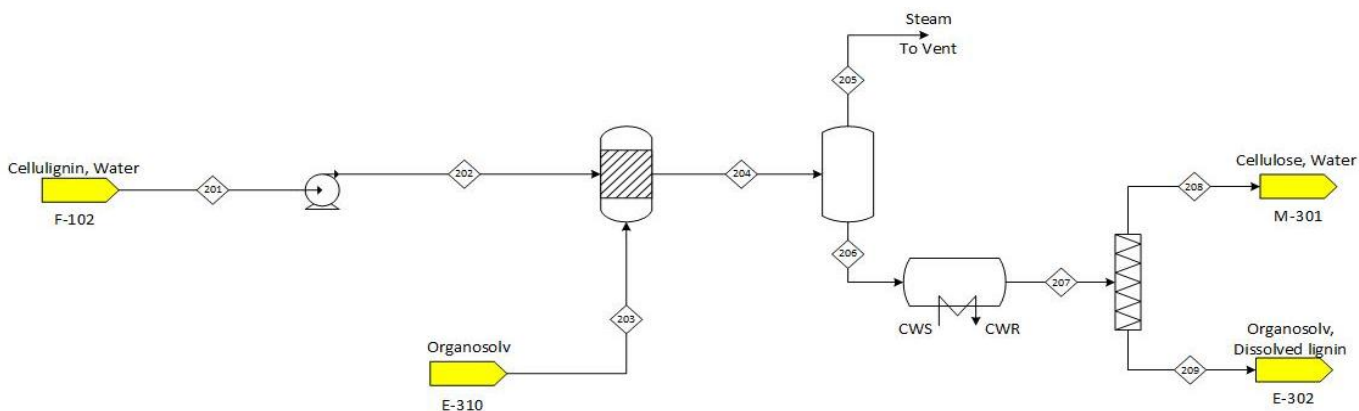

Fig. 2. The second pretreatment process happens in Unit 200, delignification. Cellulignin is pressurised with Organosolv, sent to a reactor where lignin is separated from cellulose. This is followed by filtration to separate cellulose from dissolved lignin in Organosolv. 

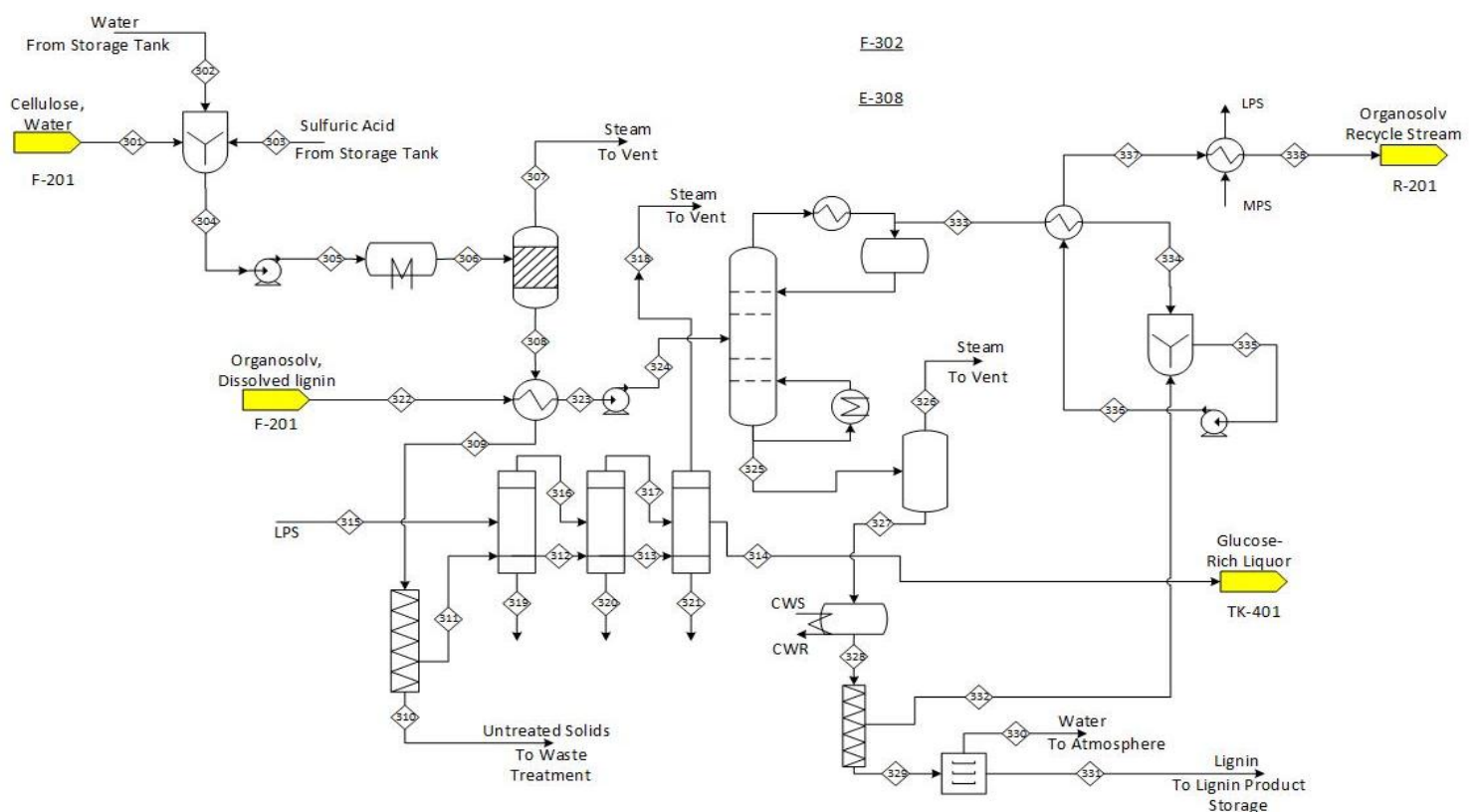

Fig. 3. In Unit 300 cellulose is hydrolyzed into glucose and concentrated in a triple effect evaporator to form the glucose rich liquor. To save energy the Organosolv Recovery utilizes heat from hydrolysis to preheat the Organosolv-Lignin stream.

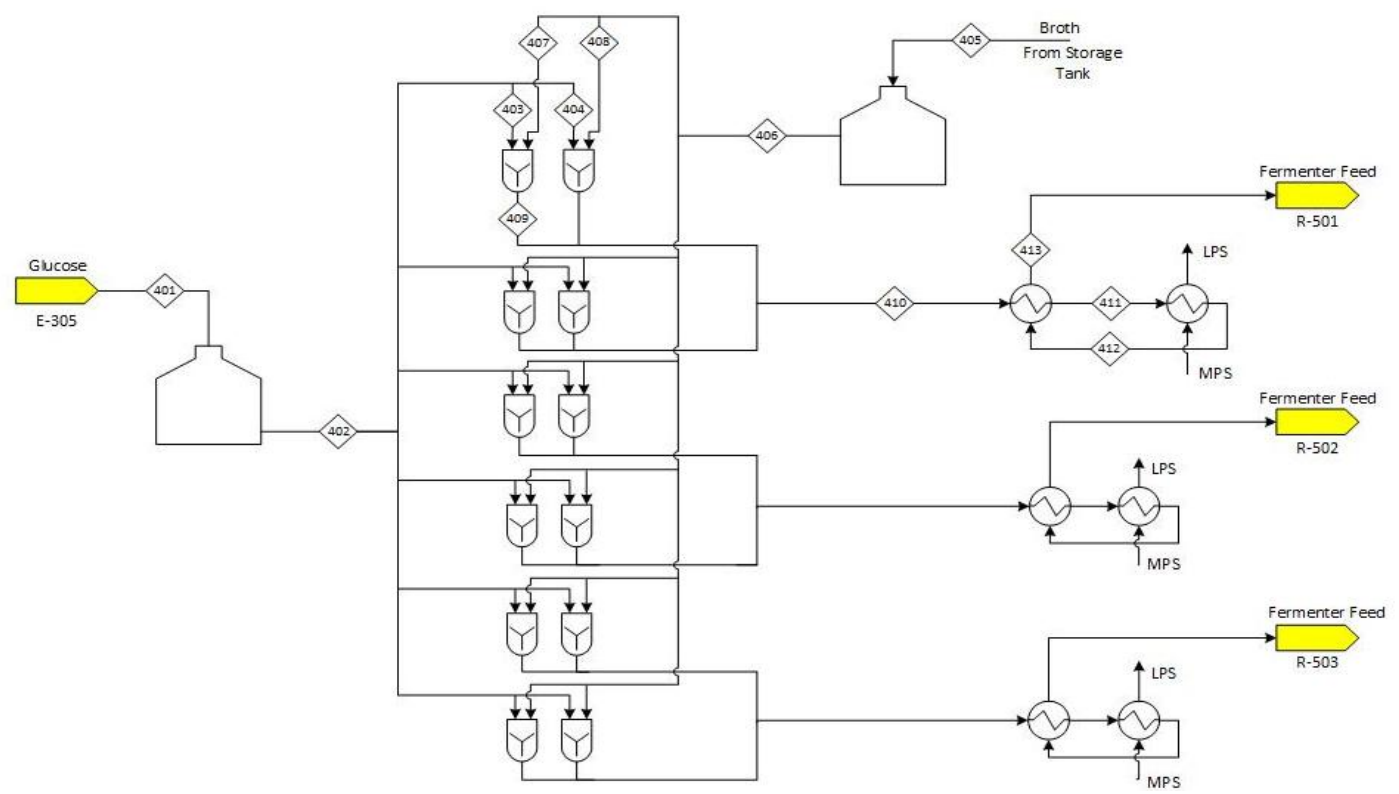

Fig. 4. In Unit 400, Pre-Fermentation, glucose is combined with the constituents of the fermentation broth which is then pasteurized.

The spent organosolv stream is preheated from $90^{\circ} \mathrm{C}$ to $180^{\circ} \mathrm{C}$ and pumped to $480 \mathrm{kPa}$ before entering the distillation column to recover all the ethanol and the dissolved lignin goes to the bottoms with water. The lignin-water mixture is sent to a flash drum to precipitate the lignin. The mixture is then cooled to $90^{\circ} \mathrm{C}$ before it is filtered. The solid lignin is then dried and sent to a storage tank at a rate of $9,464 \mathrm{~kg} / \mathrm{h}$. The recovered ethanol is further cooled from $125^{\circ} \mathrm{C}$ to $90^{\circ} \mathrm{C}$. The water from the filtered lignin, and the recovered ethanol are mixed together in a vessel before it is recycled back to the delignification section, creating a closed-loop system of an Organosolv recovery system.

\section{Fermentation}

The fermentation part is divided into the pre-fermentation and the fermentation sections shown in Fig. 4 and 5, respectively. Glucose solution from cellulose hydrolysis section is stored in a holding tank with a capacity of 85,600 L. Glucose solution is then divided into six streams which are further divided into two streams to enter a total of 12 mixing vessels at a mass flowrate of $5,917.81 \mathrm{~kg} / \mathrm{h}$. These mixing vessels will not operate simultaneously since the whole fermentation part of the plant operates in batch. The 12 mixing vessels will be separated into three units, one for each fermentation unit.

Another component entering the mixer is the broth in which the bacteria culture will thrive. The broth with composition described by Yang and Tsao [7] as listed in Table II, will enter the mixing vessel at $18,955.07 \mathrm{~kg} / \mathrm{h}$.

TABLE II: COMPOSITION OF THE BROTH MEDIUM

\begin{tabular}{llll}
\hline \hline Component & $\begin{array}{l}\text { Flowrate } \\
(\mathrm{kg} / \mathrm{h})\end{array}$ & Component & $\begin{array}{l}\text { Flowrate } \\
(\mathrm{kg} / \mathrm{h})\end{array}$ \\
\hline$\left(\mathrm{NH}_{4}\right)_{2} \mathrm{SO}_{4}$ & 49.32 & $\mathrm{MnSO}_{4}-\mathrm{H}_{2} \mathrm{O}$ & 0.25 \\
$\mathrm{KH}_{2} \mathrm{PO}_{4}$ & 18.49 & $\mathrm{~L}-(+)$-cysteine & 12.33 \\
$\mathrm{~K}_{2} \mathrm{HPO}_{4}-3 \mathrm{H}_{2} \mathrm{O}$ & 18.49 & Yeast Extract & 123.29 \\
$\mathrm{FeSO}_{4}-7 \mathrm{H} 2 \mathrm{O}$ & 0.25 & Asparagine & 49.32 \\
$\mathrm{MgSO}_{4}-7 \mathrm{H}_{2} \mathrm{O}$ & 4.93 & Water & $18,653.76$ \\
$\mathrm{NaCl}$ & 24.66 & & \\
\hline \hline
\end{tabular}




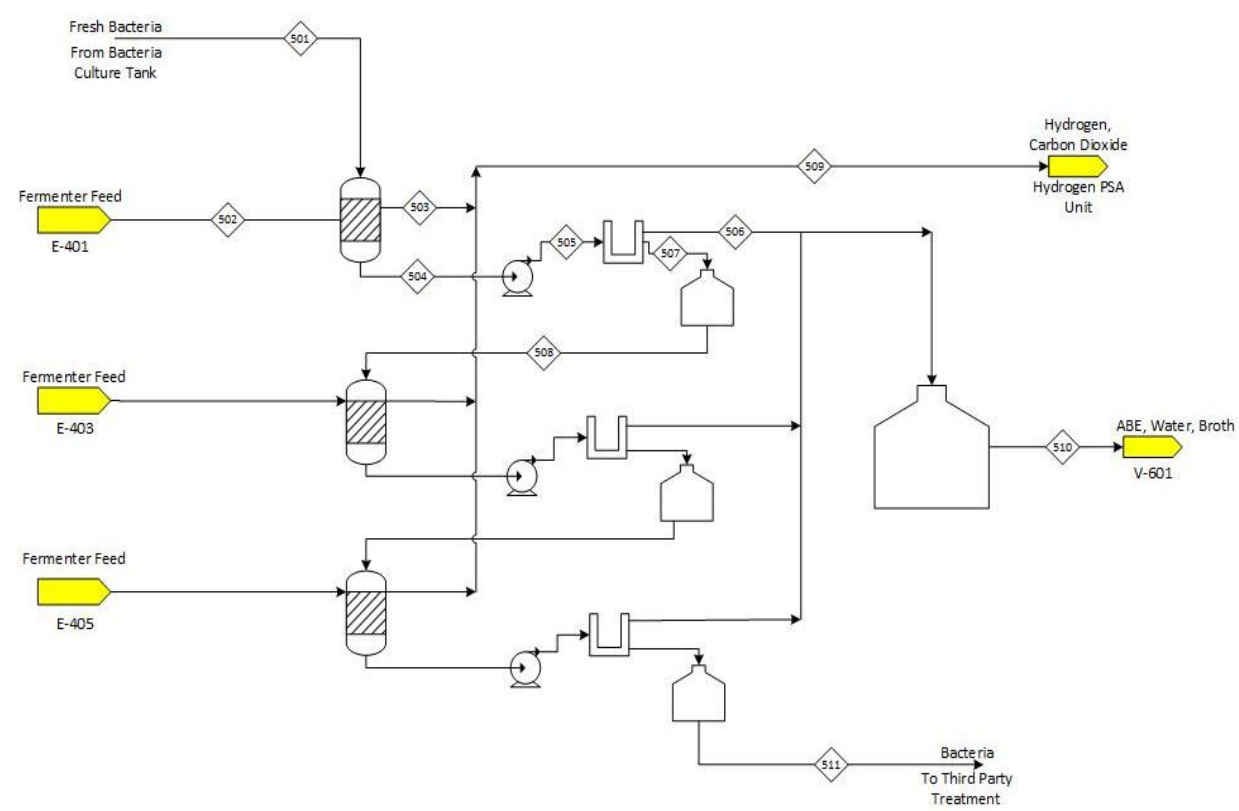

Fig. 5. Unit 500 is the Fermentation process where pasteurized fermentation broth is converted into Acetone, Butanol, Ethanol, Hydrogen and Carbon dioxide by a Clostridium acetobutylicum culture.

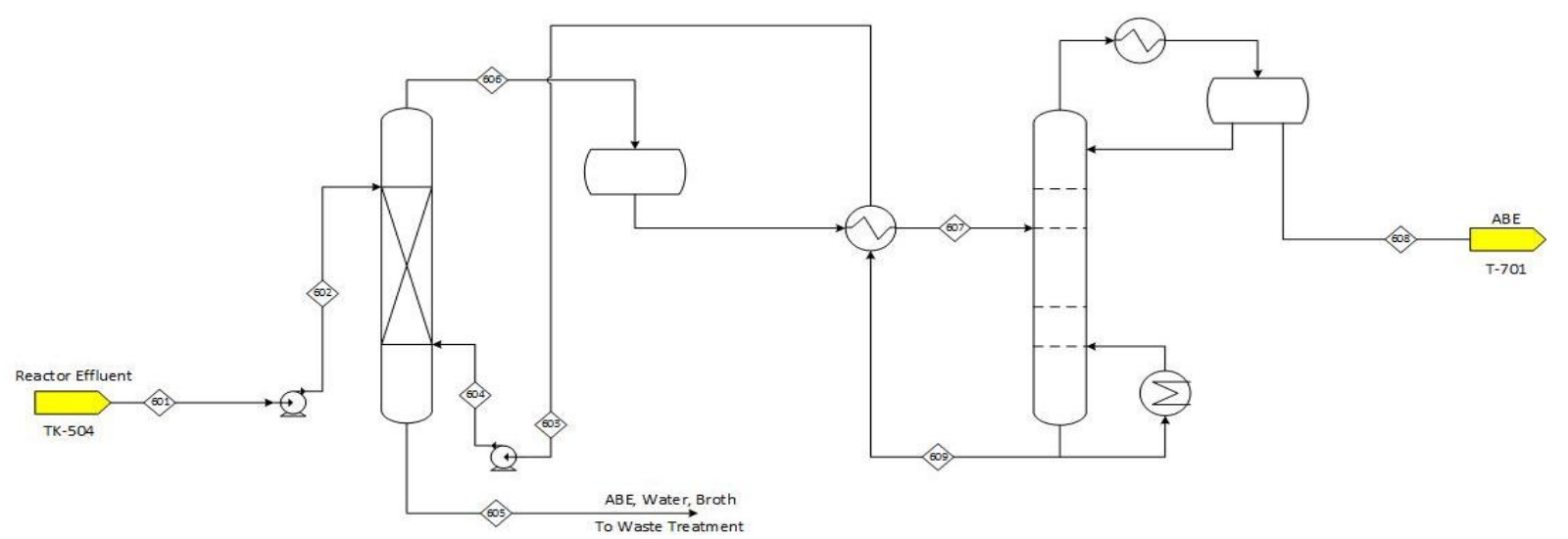

Fig. 6. ABE are extracted from the broth using liquid-liquid-extraction in Unit 600.

The feed solutions of glucose, water, and broth from four mixing vessels are combined and pasteurized before entering its corresponding fermentation unit. The fermentation section consists of three fermentation units operating in batch. Each fermentation unit is 8 hours out of phase with one another to incorporate a pseudo-continuous process. Each unit has two fermenters with a capacity of $1,350 \mathrm{~m}^{3}$. The entering bacteria at the first unit is at a rate of $105.89 \mathrm{~kg} / \mathrm{h}$. Fermentation will run for 24 hours, then it is drained, washed, stripped of oxygen, and re-filled with the feed.

The bottom stream consists of liquids - water, acetone, butanol, ethanol, and a few unreacted glucose, and broth and the solid cell mass. This mixture proceeds to a centrifuge, separating the cells from the liquid. The bacteria cells proceed to a holding tank before it is reused in the next fermentation unit. This process is repeated until the bacteria are used three times. The spent bacteria then proceed to a third-party wastewater treatment facility. The liquid products are then sent to the ABE holding tank at a rate of $48,089 \mathrm{~kg} / \mathrm{h}$ per fermenter. Gas products are vented out of each fermenter at $1,363.43 \mathrm{~kg} / \mathrm{h}$. The non-condensable product gases hydrogen and carbon dioxide - proceeds to the gas purification section.

\section{Purification}

The purification part is divided into the $\mathrm{ABE}$ extraction section, the distillation section, and the gas purification section shown in Fig. 6, 7 and 8, respectively. The ABE-water stream at $96,177 \mathrm{~kg} / \mathrm{h}$ is pumped to $150 \mathrm{kPa}$ to the top of the liquid-liquid extraction unit and the solvent, oleyl alcohol, enters at the bottom at the same pressure. The raffinate at the bottom contains mostly water and minute concentrations of ABE. The raffinate is then sent to a third-party wastewater treatment. All of the solvent proceed to the extract phase with ABE. The extract phase has a flowrate of $130,375 \mathrm{~kg} / \mathrm{h}$. It is then pumped to $291.325 \mathrm{kPa}$ and preheated to $320^{\circ} \mathrm{C}$ before entering the distillation column. All of the solvent is recovered at the bottom and is recycled back to the extraction unit.

The ABE-rich stream at $2325.75 \mathrm{~kg} / \mathrm{h}$ proceeds to the distillation section. Acetone still produces $857.80 \mathrm{~kg} / \mathrm{h}$ of $99.75 \%$ pure acetone in the distillate. Butanol is recovered in the second distillation, which produces $988.02 \mathrm{~kg} / \mathrm{h}$ of $99 \%$ pure butanol at the bottoms. Finally, ethanol is recovered in the last column at $444.51 \mathrm{~kg} / \mathrm{h}$ as $98 \%$ ethanol in the distillate stream. The bottoms stream of the last column proceeds to wastewater treatment.

The gas products are separated using two PSA units: one for hydrogen and one for carbon dioxide. The hydrogen PSA unit produces $99.99 \%$ pure hydrogen at a rate of $326.30 \mathrm{~kg} / \mathrm{h}$, and the carbon dioxide PSA unit produces $99.99 \%$ pure carbon dioxide at a rate of $7854.3128 \mathrm{~kg} / \mathrm{h}$. The inert gas 
nitrogen is recycled for blanketing.

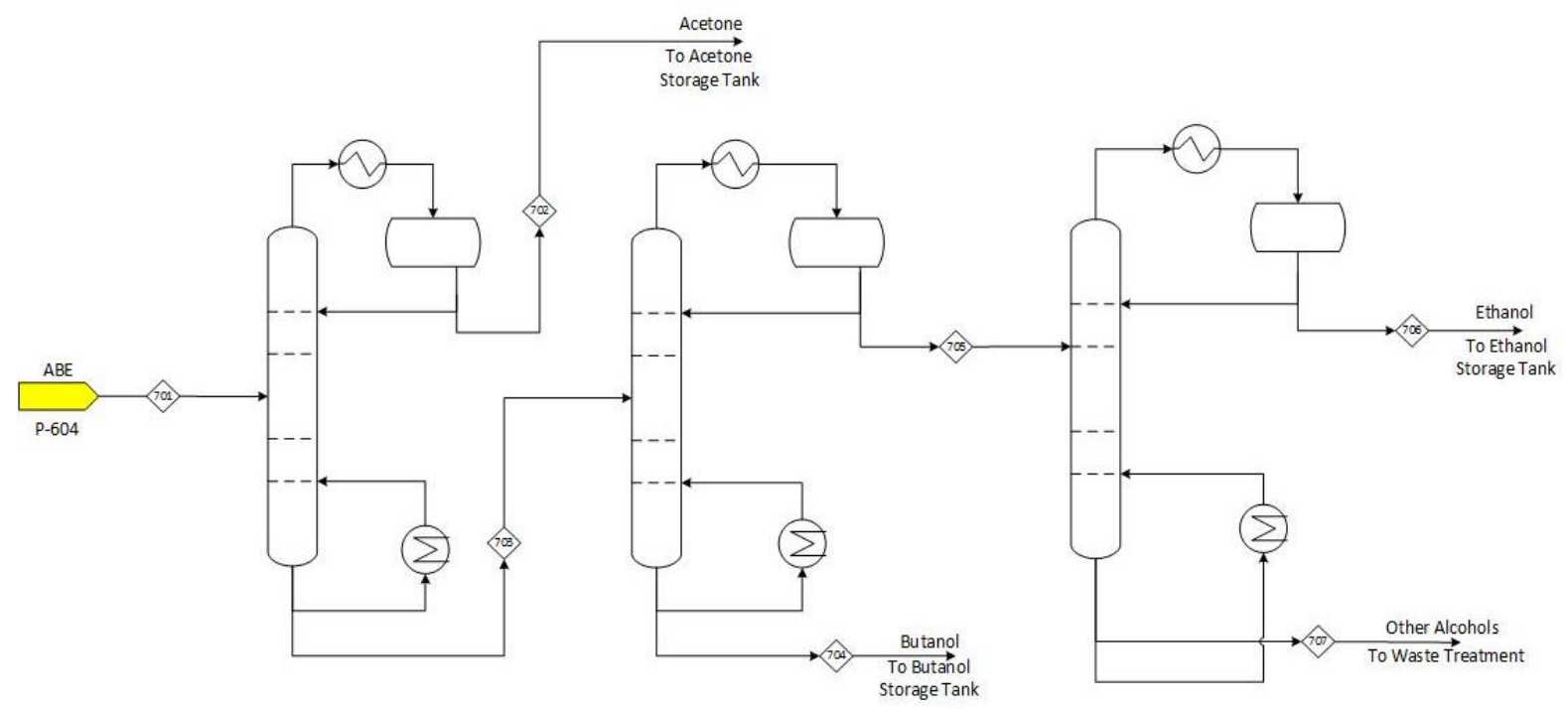

Fig. 7. ABE are separated in Unit 700 to product specifications by a sequence of distillation units.

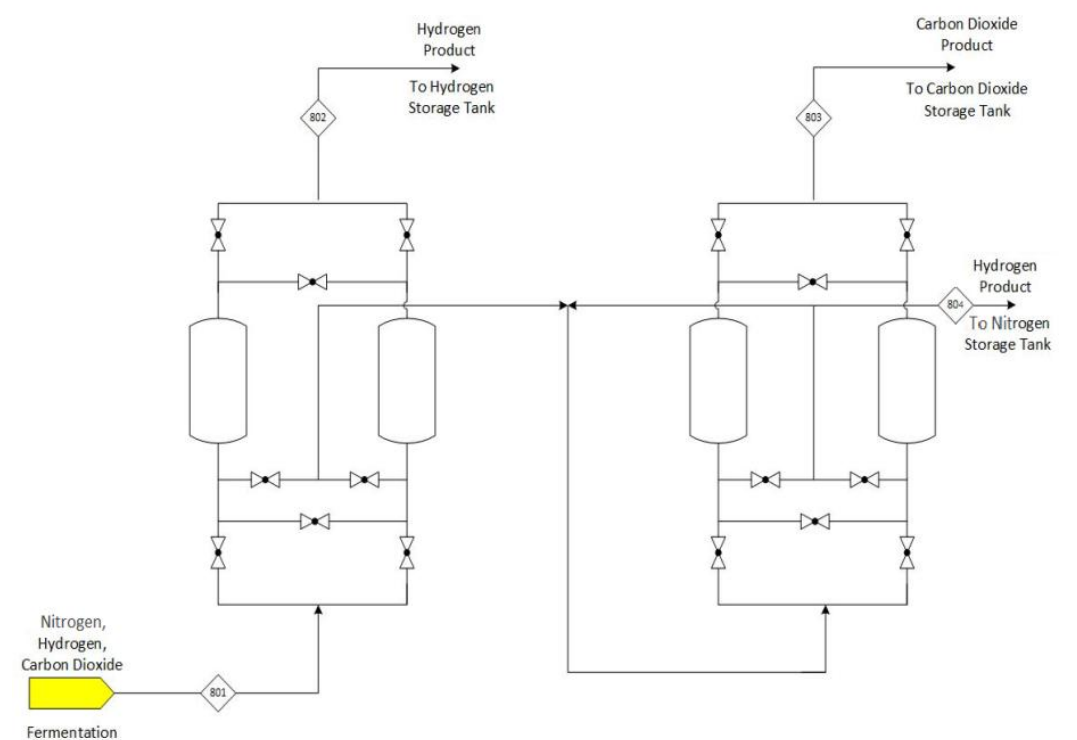

Fig. 8. In Unit 800, Gas Purification is achieved by a sequence of pressure swing adsorption systems.

\section{E. Economics}

The calculation of total capital investment is summarized in Table III. In the calculation of the cash flow, startup expenses are assumed to be lumped with the working capital. The total capital investment of the preliminary design of ABE fermentation is USD 389M.

TABLE III: CALCULATION OF TOTAL CAPITAL INVESTMENT

\begin{tabular}{lr}
\multicolumn{2}{c}{ TABLE III: CALCUlATION OF Total CAPITAL INVESTMENT } \\
\hline \hline Inside Battery Limits (ISBL) Investment & Total Cost (USD) \\
Outside Battery Limits (OSBL) Investment & $174,266,000$ \\
Contingency Charges & $69,707,000$ \\
Startup & $24,397,300$ \\
Working Capital & $80,511,090$ \\
Fixed Capital Investment & $40,255,545$ \\
Total Capital Investment & $268,370,300$ \\
\hline \hline
\end{tabular}

Operating costs include variable costs of production sales revenue, cost of raw materials, utilities, consumables and effluent disposal - and fixed costs of production - operating labor, supervision, etc. Table IV lists all calculations for the operating costs of 330 days or 7,920 hours of operation.

TABLE IV: REVENUE AND PRODUCTION COSTS

\begin{tabular}{lcc}
\hline & & Total Cost (USD) \\
\hline $\begin{array}{l}\text { Products (Acetone, Butanol, } \\
\text { Ethanol, Lignin, } \mathrm{CO}_{2}, \mathrm{H}_{2} \text { ) }\end{array}$ & Annual Revenue: & $528,163,758$ \\
\hline Raw Materials & & $136,737,428$ \\
Utilities, Consumables, & Annual Cost: & $102,827,335$ \\
$\begin{array}{l}\text { Effluent Disposal } \\
\text { Fixed Costs of Production }\end{array}$ & & $15,133,964$ \\
\hline \hline
\end{tabular}

During the investing phase, four different scenarios were taken into account for the construction period of the plant. The scenario with the least expenditure is one with one-time loan from the bank for the basis of FCI. A two-year construction period was taken into account with the first year using all of the equity and the rest is loaned from the bank (40\% and then $60 \%$ for years 1 and 2, respectively) resulted to an interest charge of USD 9,680,000. This scenario was 
chosen as the basis for cash flow of construction costs for this design. It is noted that for all the cases aforementioned, the interest rate used is $6 \%$.

Cash flow is calculated with a salvage value of $15 \%$ of FCI, and 10-year depreciable life. Depreciation was calculated using straight line depreciation method. As a result, an IRR of $28 \%$ was achieved by the proposed plant operations with a total accumulated net present value of USD 707M. A straight payback of 5.44 years and discounted payback of 5.91 years is also achieved in this preliminary design.

The net cash flow diagram shown in Fig. 9 indicates an expected positive flow of cash by the start of sales. On the first year of sales, it was based upon that only $30 \%$ of the sales are achieved in the operating year while it is $90 \%$ in the second year. The rest of the years will then have $100 \%$ sales per year. At the end of 10 years, depreciation, working capital and land costs will be accounted back as forms of cash flow input.

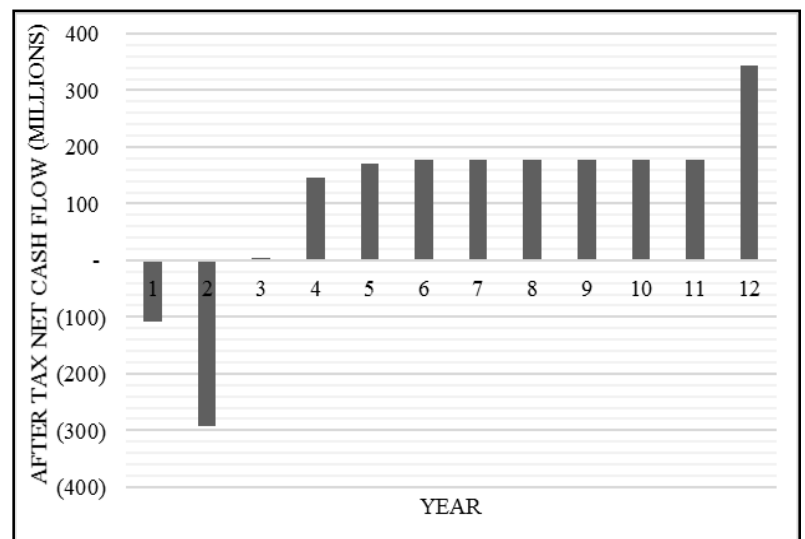

Fig. 9. The cash flow diagram shows a positive cash flow at year 3 during the first year of sales.

In the sensitivity analysis, the cost of goods sold (COGS) is more variable and dependent on the changes in the percentage sales. From Fig. 10, the slope of FCI vs discounted payback is 2.2 while that of COGS is 5.5. Thus, COGS tend to change more dramatically with respect to percentage sales. That is because the FCI is primarily dependent on heuristics and cost of equipment which are nearly fixed as compared to COGS that is highly dependent on the amount produced due to higher values of variable costs.

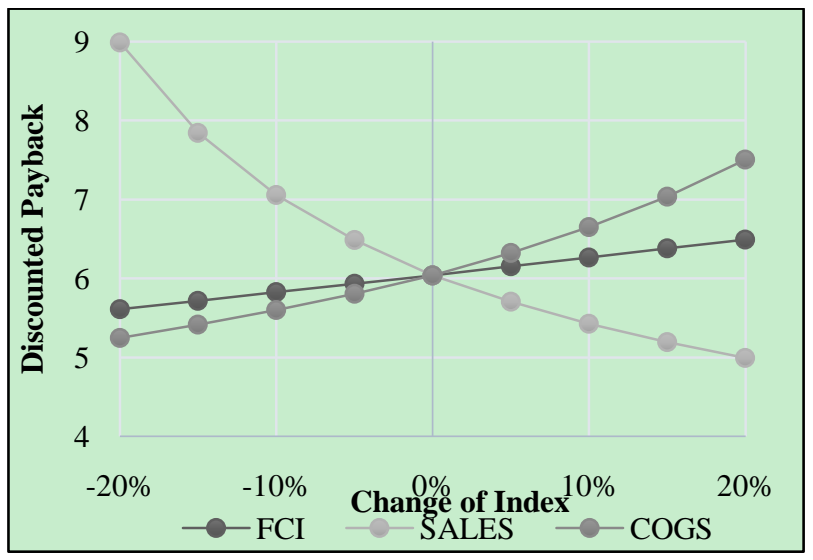

Fig. 10. Sensitivity plot shows that the discounted payback is most sensitive to the cost of goods sold.

The breakeven point obtained is $29.18 \%$, shown in Fig 11.
This explains the positive cash flow at the start of its operation, having $30 \%$ sales procurable.

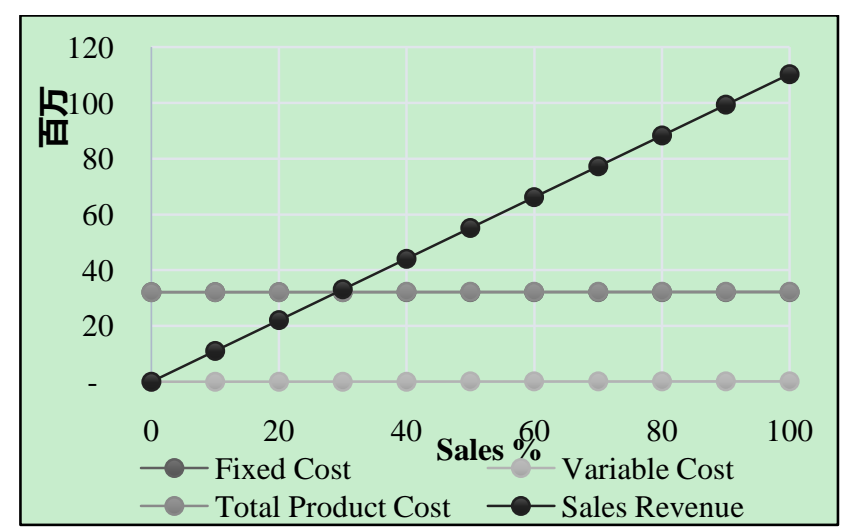

Fig. 11. The breakeven even point occurs at $30 \%$ of sales.

A comparison of the results in this study is shown in Table V. Although this study used half the butanol yield and a lower sugar feed rate, the IRR is better than the result of the simulation by Mariano et al. Though the IRR of this study is inferior to that of Mansur et al, the study period differs greatly. The Net Present Value of this study at USD 707M is much higher than the USD $118.8 \mathrm{M}$ from Mansur et al. The better profitability in this study may be attributed to the utilization of low cost sugarcane bagasse as the process feed.

\begin{tabular}{llll}
\multicolumn{4}{c}{ TABLE V: COMPARISON WITH OTHER STUDIES } \\
\hline \hline & Mansur et al. [8] & $\begin{array}{c}\text { Mariano } \text { et } \\
\text { al. } \text { [9] }\end{array}$ & This study \\
\hline Bacteria & $\begin{array}{l}\text { Novel } \\
\text { Clostridium } \\
\text { strain }\end{array}$ & $\begin{array}{l}\text { Clostridium } \\
\text { beijerinckii }\end{array}$ & $\begin{array}{l}\text { Clostridium } \\
\text { acetobutylicum }\end{array}$ \\
$\begin{array}{l}\text { Yield } \\
\text { (g Butanol/g } \\
\text { sugar) }\end{array}$ & 0.2236 & 0.34 & 0.17 \\
$\begin{array}{l}\text { Feed } \\
\begin{array}{l}\text { Sugar feed } \\
\text { rate (tons/yr) } \\
\text { IRR }\end{array}\end{array}$ & Sugarcane juice & $\begin{array}{l}\text { Sugarcane } \\
\text { juice }\end{array}$ & $\begin{array}{l}\text { Sugarcane } \\
\text { bagasse }\end{array}$ \\
$\begin{array}{l}\text { Net present } \\
\text { value }\end{array}$ & USD 118.040 & $2,000,000$ & 140,607 \\
Study period & 20 years & 14.80\% & 28\% \\
\hline \hline
\end{tabular}

\section{CONCLUSION}

This feasibility report showed that a sugarcane bagasse based ABE biorefinery in the Philippines may very well be realized. With an IRR of $28 \%$ and a payback of 5.44 years, the detailed design of this biorefinery should be further explored.

For the optimization of process streams inside the plant, there are several opportunities to save on utilities. The various streams containing steam from several reactors and flash drums could be used to heat some of the process fluids, instead of relying on heating coils. The distillate from the multiple-effect evaporator may be used as the washing solvent for the bagasse and the make-up water at the beginning of the cellulose hydrolysis section. Another use for the steam is for the generation of electricity to cut back on energy-intensive processes, including the ball mill, mixers coupled with heaters, and the centrifuges. A fraction of the lignin may also be utilized as fuel for the boilers. 


\section{REFERENCES}

[1] D. T. Jones and D. R. Woods, "Acetone-butanol fermentation revisited," Microbiological Reviews, vol. 50, no. 4, 484-524, 1986.

[2] G. Towler and R. Sinnott, Chemical Engineering Design, London: Elsevier, Inc, 2008.

[3] M. S. Peters and K. D. Timmerhaus, 1991, Plant Design and Economics for Chemical Engineers. Singapore: McGraw-Hill, Inc.

[4] L. HCE, Pumped carbon mining (PCM) substitute natural gas (SNG) production cost estimate, 2004

[5] S. Jenkins, "Current economic trends," Chemical Engineering Magazine, p. 96, March 2016.

[6] J. Gapes, "The economics of acetone-butanol fermentation: theoretical and market considerations," Journal of Molecular Microbiology and Biotechnology, vol. 2, no. 1, 27-32, 2000.

[7] X. Yang and G. T. Tsao, "Mathematical modeling of inhibition kinetics in acetone-butanol fermentation by Clostridium acetobutylicum," Biotechnology Progress, vol. 10, pp. 532-538, 1994.

[8] M. C. Mansur, M. K. O'Donnell, M. S. Rehmann, and M. Zohaib, “ABE Fermentation of Sugar in Brazil," Senior Design Reports, Dept. of Chem. And Biomol. Eng., Univ. of Pennsylvania, Philadelphia, USA, 2010.

[9] A. P. Mariano, M. O. S. Dias, T. L. Junqueira, M. P. Cunha, A. Bonomi and R. W. Filho, "Butanol production in a first-generation Brazilian sugarcane biorefinery: Technical aspects and economics of greenfield projects," Bioresource Tech., vol. 135, pp. 316-323, May 2013.

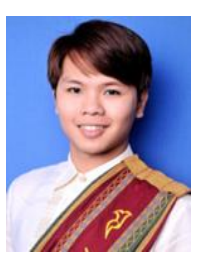

Charlimagne M. Montealegre completed his BS and MS degree in chemical engineering at the University of the Philippines Diliman, Quezon City Philippines.

$\mathrm{He}$ is currently an Assistant Professor in the same university, an active member of the Bioprocess Engineering Laboratory and the Assistant Chairman of the Department of Chemical Engineering. His research interests include bioprocessing, industrial natural products extraction and their applications.

Asst. Prof. Montealegre currently holds the UP KEMGLOBAL Dr. Luz
Salonga Professorial Chair in Chemical Engineering, is the adviser of UP Academic League of Chemical Engineering Students and is a member of the Philippine Institute of Chemical Engineers.

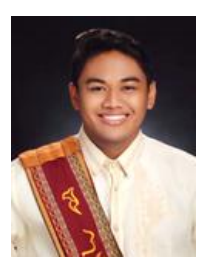

John Mark Edrhum M. Ani is currently taking his degree in bachelor of science in chemical engineering in the University of the Philippines Diliman (UP Diliman). He worked part-time as a student laboratory assistant in the Department of Chemical Engineering in UP Diliman from 2015-2016. Mr. Ani was a member of the Executive Committee of UP Batangan where he served as the vice-chairperson for internal affairs for the academic year 2013-2014, and the Batch Representative for the academic year 2015-2016.

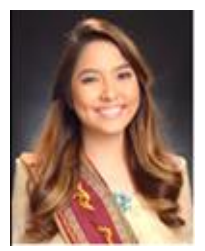

Onella Kezia B. Castro is currently taking her bachelor of science degree in chemical engineering in the University of the Philippines Diliman (UP Diliman). She is a member of the University of the Philippines Chemical Engineering Society, Inc (UP KEM).

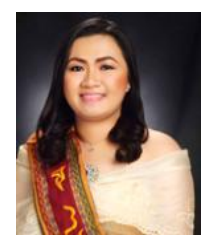

Lara Louise R. Llanera is currently taking her undergraduate degree in bachelor of science in chemical engineering in the University of the Philippines Diliman (UP Diliman). She is a member of University of the Philippines Chemical Engineering Society, Inc. (UP KEM). Together with Mr. Ani and Ms. Castro, she is also working on a study focused on the design and stabilization of a transdermal drug delivery system under the Bioprocess Engineering Laboratory of the Department of Chemical Engineering, UP Diliman. 